\title{
Detection of human parvovirus B19 in a patient with hepatitis
}

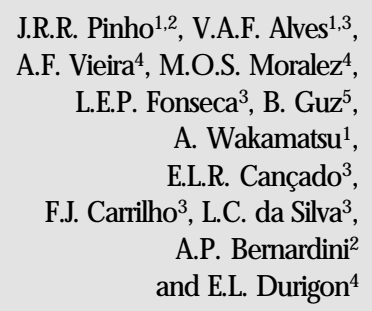

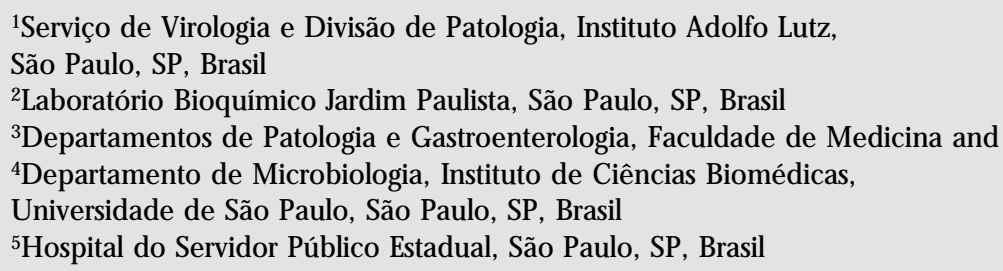

${ }^{1}$ Serviço de Virologia e Divisão de Patologia, Instituto Adolfo Lutz, São Paulo, SP, Brasil ${ }^{2}$ Laboratório Bioquímico Jardim Paulista, São Paulo, SP, Brasil ${ }^{3}$ Departamentos de Patologia e Gastroenterologia, Faculdade de Medicina and ${ }^{4}$ Departamento de Microbiologia, Instituto de Ciências Biomédicas, Universidade de São Paulo, São Paulo, SP, Brasil ${ }^{5}$ Hospital do Servidor Público Estadual, São Paulo, SP, Brasil

\section{Correspondence}

J.R.R. Pinho

Serviço de Virologia

Instituto Adolfo Lutz

Av. Doutor Arnaldo, 355

01246-902 São Paulo, SP

Brasil

Fax: +55-11-3885-7955

E-mail: jrrpinho@usp.br

Research partially supported by FAPESP (No. 97/4955-0).

Received February 13, 2001 Accepted May 29, 2001

\section{Abstract}

Parvovirus B19 has been associated by some investigators with cases of severe hepatitis. The aim of the present study was to determine the presence of active parvovirus B19 infection among 129 Brazilian patients with non-A-E hepatitis. The patients were assayed for antibodies against parvovirus B19, IgM class, by ELISA. In IgM-positive cases, parvovirus B19 DNA was assayed by PCR in serum and liver tissue and parvovirus VP1 antigen in liver tissue was assayed by immunohistochemistry. Antibodies against parvovirus B19, IgM class, were detected in $3(2.3 \%)$ of 129 patients with non-A-E hepatitis. Previous surgery and blood transfusions were reported by these 3 patients. One patient was a 56-year-old female with severe hepatitis, with antimitochondrial antibody seropositivity and submassive necrosis at liver biopsy, who responded to corticosteroid therapy. Strong evidence for active parvovirus B19 infection was found in this patient, with parvovirus B19 DNA being detected by PCR in liver tissue. Furthermore, parvovirus VP1 antigen was also detected in liver tissue by immunohistochemistry. The other two IgM-positive patients were chronic hepatitis cases, but active infection was not proven, since neither viral DNA nor antigen were detected in their liver tissues. This and other reports suggest a possible relation between parvovirus B19 infection and some cases of hepatitis.

\section{Introduction}

Human parvovirus B19 is a member of the Parvoviridae family, genus Erythrovirus. This is a non-enveloped virus containing a single copy, single-stranded linear DNA molecule with approximately 5,000 nucleotides that codes for two major structural or capsid proteins, VP1 and VP2, and one nonstructural protein, NS1. The genome is

\section{Key words}

- Parvovirus B19

- Hepatitis non-A-E

- Autoimmune hepatitis

- Polymerase chain reaction

- Immunohistochemistry 
eases (transient aplastic crisis in patients with low red cell production, spontaneous abortions, hydrops fetalis, and fetal death). Parvovirus B 19 has also been related to cases of hemophagocytic syndrome, myocarditis, neurological disease, systemic vasculitis, and hepatitis, though additional studies are needed to confirm the role of B19 in these diseases (2).

Liver dysfunctions associated with parvovirus B19 have been described by several authors, especially involving acute hepatitis cases (3-12), and the transmission of parvovirus B19 to patients with liver diseases has possibly led to exacerbations of disease in patients with cirrhosis (13) and liver transplant (14).

In this study, we investigated the presence of human parvovirus B19 infection in 129 patients with non-A-E hepatitis followed up in São Paulo, Brazil, by the detection of anti-B19 antibodies (IgM) by ELISA. To confirm the presence of parvovirus infection in the liver, the patients were further assayed for B19 DNA by PCR and for VP1 antigen by immunohistochemistry.

\section{Patients and Methods}

\section{Patients}

We studied 129 patients with acute or chronic hepatic disorders for whom viral hepatitis was considered in the differential diagnosis. These patients were seronegative for $\mathrm{HBsAg}$, anti-HBc and anti-HCV antibodies as determined with commercially available kits (Abbott Laboratories, Chicago, IL, USA). Acute cases also tested negative for anti-HAV IgM, anti-HBc IgM, anti-HEV antibodies (Abbott) and HCV-RNA by RTPCR using previously described primers $(15,16)$ after guanidine isothiocyanate extraction (17).

This research was approved by the Ethics Committee of the Hospital das Clínicas, Faculdade de Medicina, USP.

\section{Biopsies}

Liver biopsies were performed using a Tru-Cut ${ }^{\mathrm{TM}}$ needle and liver histology was evaluated blindly by two specialized pathologists.

\section{Enzyme immunoassay for anti-parvovirus B19 antibodies (ELISA)}

Serum samples from all patients were analyzed for IgM-specific antibodies specific for B19 as previously described by Erdman et al. (18), using as antigen the B19 capsid protein expressed in baculovirus (19).

\section{PCR for parvovirus B19 DNA}

Paraffin-fixed liver biopsy specimens were cut into $0.7-\mu \mathrm{m}$ thick fragments with new blades. The fragments were transferred to $1.5-\mathrm{ml}$ tubes and treated with xylene and absolute ethanol. After drying, the pellets were incubated at $37^{\circ} \mathrm{C}$ for $48 \mathrm{~h}$ in $180 \mu \mathrm{l}$ of sample buffer (10 mM Tris- $\mathrm{HCl}, \mathrm{pH} 8.0,10$ $\mathrm{mM} \mathrm{NaCl}, 1 \mathrm{mM}$ EDTA, $1 \%$ sodium dodecyl sulfate, and $500 \mu \mathrm{g} / \mathrm{ml}$ proteinase $\mathrm{K}$ ). After digestion, the samples were extracted sequentially with equal volumes of phenol, phenol-chloroform-isoamyl alcohol, and chloroform-isoamyl alcohol and finally resuspended in $30 \mu \mathrm{l}$ of MilliQ water. To confirm the absence of Taq DNA polymerase inhibitors, extracted DNA was first amplified with $ß$ actin-specific primers. PCR/nested PCR assay was carried out as described by Durigon et al. (20). For PCR, the oligonucleotide primers used were P1 (5' AAT ACA CTG TGG TTT TAT GGG CCG 3') and P6 (5' CCA TTG CTG GTT ATA ACC ACA GGT 3'), nucleotide sequences 13991422 and 1682-1659, respectively. For nested $\mathrm{PCR}$, the oligonucleotide primers used were P2 (5' CCA TTG CTG GTT ATA ACC ACA GGT 3') and P5 (5' CTA AAA ATG GCT TTT GCA GCT TCT AC 3'), nucleotide sequences 1498-1525 and 1600-1576, re- 
spectively. The extracted DNA (10 $\mu \mathrm{l})$ was added to the PCR mixture containing $10 \mu \mathrm{l}$ of 10X reaction buffer (Applied Biosystems, Foster City, CA, USA); $200 \mu \mathrm{M}$ each dATP, dCTP, dGTP, dTTP; $0.5 \mu \mathrm{M}$ each oligonucleotide primer, and $2.5 \mathrm{U}$ of Taq polymerase (Applied Biosystems). The amplification step was carried out on a thermocycler 2400 (Applied Biosystems) as follows: 35 cycles, $94^{\circ} \mathrm{C}$ for $45 \mathrm{~s}, 55^{\circ} \mathrm{C}$ for $60 \mathrm{~s}, 72^{\circ} \mathrm{C}$ for $90 \mathrm{~s}$. After the first amplification, the second (nested) PCR was carried out, and $10 \mu \mathrm{l}$ of the first PCR product was added to the nested PCR mix using the specific primers. The amplified products were submitted to $1.5 \%$ agarose gel electrophoresis and ethidium bromide staining.

\section{Autoantibody profile}

Anti-smooth muscle, anti-liver kidney microsome type 1 , anti-liver cytosol type 1 , and antimitochondrial antibodies were investigated by indirect immunofluorescence using unfixed tissue sections of rodent liver, kidney and stomach (21). Antinuclear and anti-actin antibodies were processed by the same technique in acetone-fixed human fibroblasts as the substrate (22). Western blotting to identify the antigens reactive to antimitochondrial antibodies was carried out using commercial enzyme (Sigma, St. Louis, MO, USA) and bovine heart antigens (23).

\section{Detection of parvovirus B19 VP1 antigen in liver tissue by immunohistochemistry}

VP1 antigen was detected on formalinfixed paraffin-embedded 3- $\mu \mathrm{m}$ liver sections through a specific biotinylated monoclonal antibody against VP1 (MAB8292B, Chemicon International Inc., Temecula, CA, USA), diluted 1:800. Heat-induced epitope retrieval was achieved by incubation with a sodium citrate solution, $\mathrm{pH}$ 6.0, for $4 \mathrm{~min}$ in a pressure cooker. Endogenous biotin and peroxidase blocking and nonspecific protein bind- ing were performed by incubation with 1:20 normal goat serum. The immunoreaction was amplified using the high-sensitivity streptavidin-biotin-peroxidase system (LSAB, Dako Corp., Carpinteria, CA, USA), with proper controls of specificity (24).

\section{Results}

Anti-B19 IgM antibodies were detected in three $(2.3 \%)$ of 129 cases, as shown in Table 1. Previous surgery and blood transfusions were reported by the three positive patients.

Among these three cases, only the first biopsy of case 3 showed parvovirus B19 DNA (Figure 1) and VP1 antigen by immunohistochemistry (Figure 2) in the liver tissue collected at the time of the initial diagnosis of hepatitis in this patient, suggesting that parvovirus B19 was actively replicating in the liver tissue at that time. These two different viral markers were detected only in the first biopsy, but were negative in another biopsy collected several months later.

Anti-liver kidney microsome type 1 , antiliver cytosol type 1, antimitochondrial, antismooth muscle, antinuclear and anti-actin antibodies were assayed in the three cases positive for anti-B19 IgM or DNA. Only case 3 was positive for antimitochondrial antibody.

Cases 1 and 2 showed chronic liver dysfunction, with no other hepatitis-associated viruses being detected. These two patients were 70 and 78 years old, respectively, and the presence of liver disease was detected during surgery for another disorder (cholelithiasis and anovaginal fistula, for cases 1 and 2, respectively). Case 1 had normal levels of hepatic enzymes and a histological pattern of "nonspecific reactive hepatitis", with minor portal fibrosis and inflammation and with small amounts of lymphocytes, plasma cells and eosinophils. Portal triad and limiting plate were preserved. Focal hepatocytes were found to be swollen, rarely 
Figure 1. Agarose gel electrophoresis and ethidium bromide fluorescence of B19 DNA PCR and nested PCR amplification products. Lane 1, 100-bp DNA ladder. Lane 2, PCR product of a liver biopsy specimen (case 3). Lane 3, Nested PCR product of a liver biopsy specimen (case 3). Lane 4, PCR product of the control gene $B$ actin. Lane 5, PCR negative control. Lane 6, Nested PCR negative control. Lane 7 , PCR product of a B19 DNA-positive control (284 bp). Lane 8, Nested PCR product of a B19 DNA-positive control (102 bp).
Table 1. Clinical features of three patients positive for parvovirus B19 IgM and DNA.

\begin{tabular}{|c|c|c|c|}
\hline Clinical features & Case 1 (LMF) & Case 2 (EV) & Case 3 (NM) \\
\hline Sex & Male & Female & Female \\
\hline Age & 70 & 78 & 56 \\
\hline IgM anti-B19 & Positive & Positive & Positive \\
\hline B19 DNA (liver) & Negative & Negative & Positive \\
\hline VP1 antigen (liver) & Negative & Negative & Positive \\
\hline Liver biopsy & $\begin{array}{l}\text { Nonspecific reactive } \\
\text { hepatitis }\end{array}$ & Cirrhosis & $\begin{array}{l}\text { Submassive necrosis (first), } \\
\text { and liver cirhosis with inter- } \\
\text { face hepatitis, rosettes } \\
\text { and plasmocytes (second) }\end{array}$ \\
\hline Autoantibody profile & Negative & Negative & Antimitochondrial positive \\
\hline Surgery & Yes & Yes & Yes \\
\hline Blood transfusion & Yes (14 years before) & No & Yes (12 years before) \\
\hline AST (x UNV) & 0.62 & 2.05 & 46.4 \\
\hline ALT (x UNV) & 0.62 & 1.13 & 57.4 \\
\hline Alkaline phosphatase (x UNV) & 0.25 & 2.70 & 2.20 \\
\hline$\gamma \mathrm{GT}$ & 0.58 & 5.88 & 2.80 \\
\hline$\gamma$ Globulins (g/100 ml) & 1.70 & 1.28 & 2.66 \\
\hline HLA & ND & ND & DR7, DR8 \\
\hline Immunosuppressor therapy & ND & ND & Complete response \\
\hline $\begin{array}{l}\text { Score of international criteria for } \\
\text { AlH diagnosis (Ref. 37) }\end{array}$ & ND & ND & $\begin{array}{l}15 \text { (before treatment), } \\
17 \text { (after treatment, still } \\
\text { under immunosuppressor } \\
\text { therapy) }\end{array}$ \\
\hline
\end{tabular}

AST $=$ aspartate aminotransferase; ALT $=$ alanine aminotransferase; $x$ UNV $=$ times the upper normal value; $\gamma \mathrm{GT}=\gamma$-glutamyl transpeptidase; HLA = human leukocyte antigen; $\mathrm{AlH}=$ autoimmune hepatitis; $\mathrm{ND}=$ not determined.

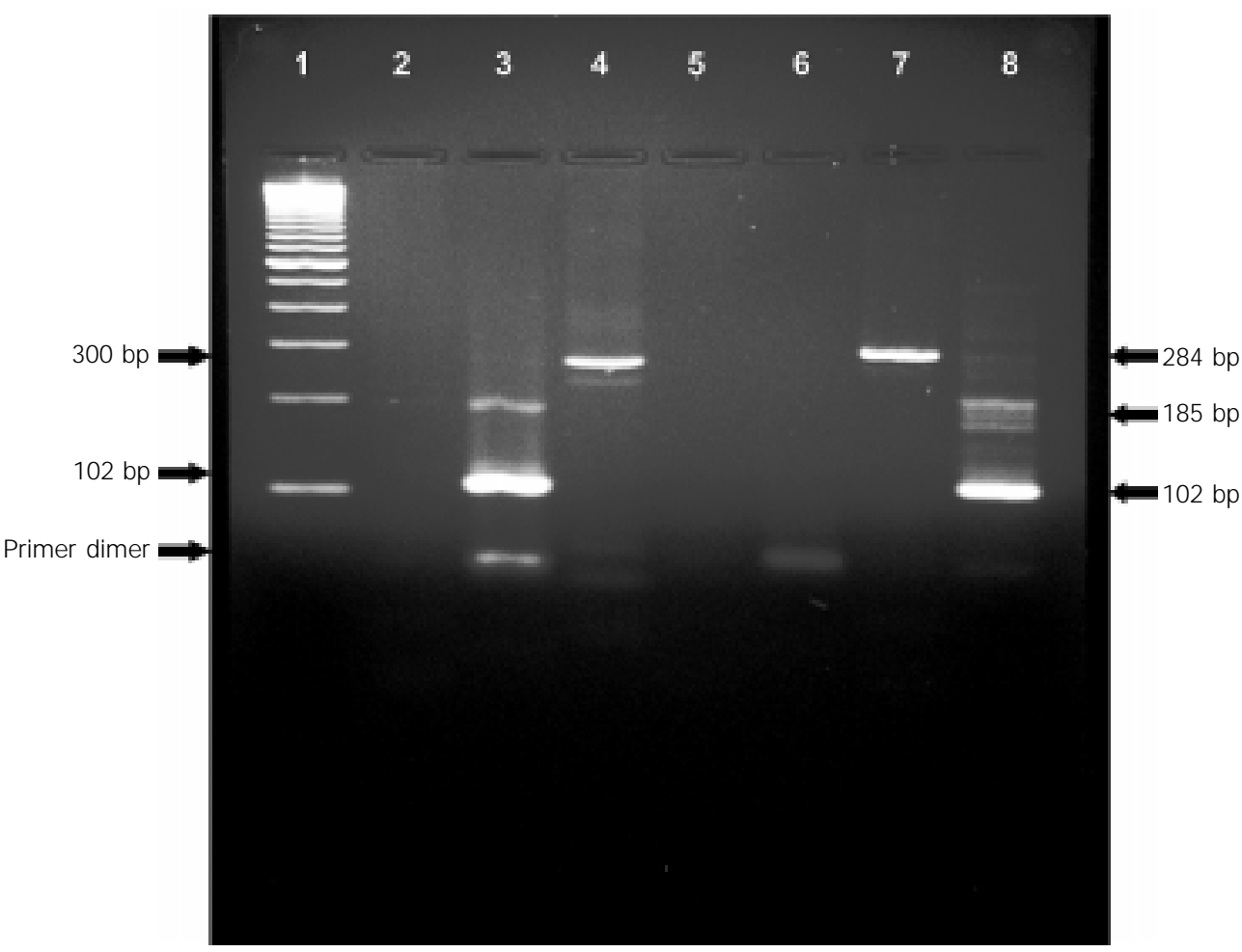


presenting lipid droplets. Scarce mononuclear infiltration was seen along the sinusoids. Case 2 had elevated liver enzymes, especially alkaline phosphatase and $\gamma$-glutamyl transpeptidase. A liver biopsy showed cirrhosis with marked septal inflammation with lymphocytes and some histiocytes. Moderate piecemeal necrosis was found. In the parenchyma, liver cells were frequently swollen, with occasional "spotty necrosis" and extensive steatosis. Another serum sample obtained from this patient one year later exhibited the same enzymatic pattern. No evidence for parvovirus infection in liver tissue was found in these two cases.

Case 3 was a 56-year-old woman with clinically severe hepatitis associated with isolated 1:80 antimitochondrial antibody, whose specificity for the pyruvate dehydrogenase complex (anti-M2) was confirmed by Western blotting. A liver biopsy revealed submassive hepatic necrosis. Several groups of apoptotic and necrotic hepatocytes were seen among small lymphocyte aggregates, with some figures of emperipolesis (Figure 3). Occasional histiocytes and plasma cells were found interspersed. In other regions of the sample, only minor liver cell damage was seen.

Parvovirus VP1 antigen was detected by immunohistochemistry in the cytoplasm of several hepatocytes, especially in those presenting remarkable swelling or undergoing acidophilic retraction (apoptosis), as shown in Figure 3.

Although antimitochondrial antibody is a classical immunological marker for primary biliary cirrhosis, biochemical tests (elevated aminotransferases, hypergammaglobulinemia, and slight alterations of alkaline phosphatase and $\gamma$-glutamyl transpeptidase) and histological findings pointed to a diagnosis of hepatitis and not to cholestasis, in spite of the presence of mild pruritus. For these reasons, case 3 was treated for autoimmune hepatitis (or a hybrid form of autoimmune hepatitis with the serological marker
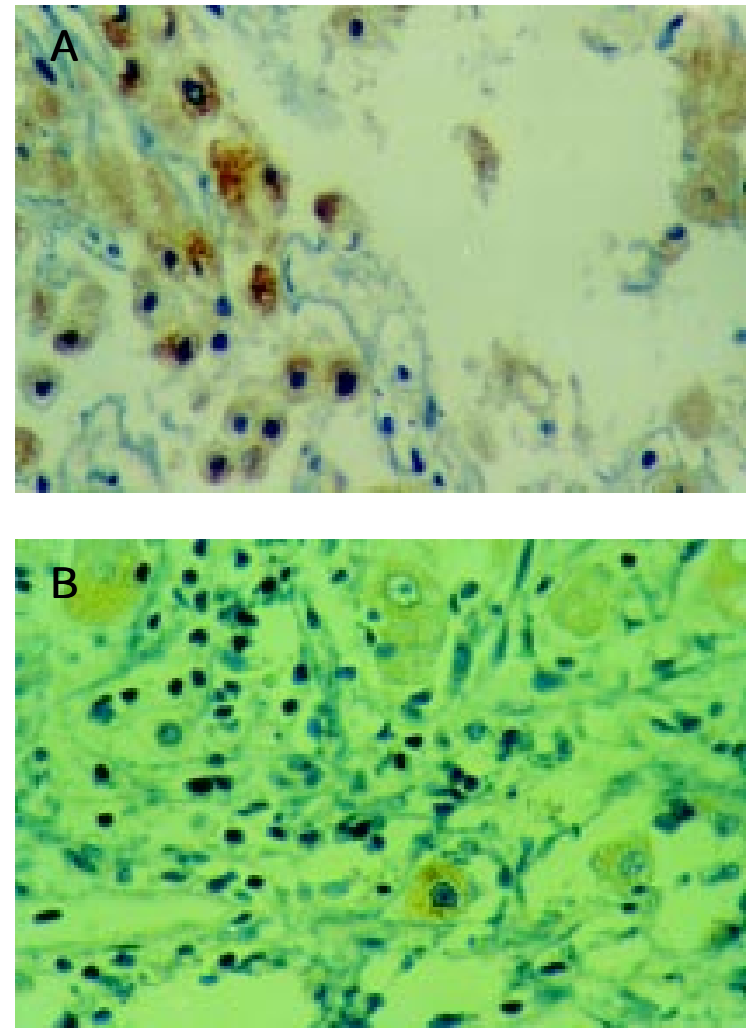

Figure 2. Immunohistochemical detection of parvovirus B19 VP1 antigen in a formalin-fixed paraffin-embedded liver biopsy (case 3). A, Several swollen or retracted centrilobular hepatocytes display VP1 antigen in granular, cytoplasmic distribution (LSAB-Peroxidase, 150X). B, High magnification view of a positive reaction for VP1 antigen in the cytoplasm of a hepatocyte immersed in mononuclear infiltrate (LSAB-Peroxidase, 600X).
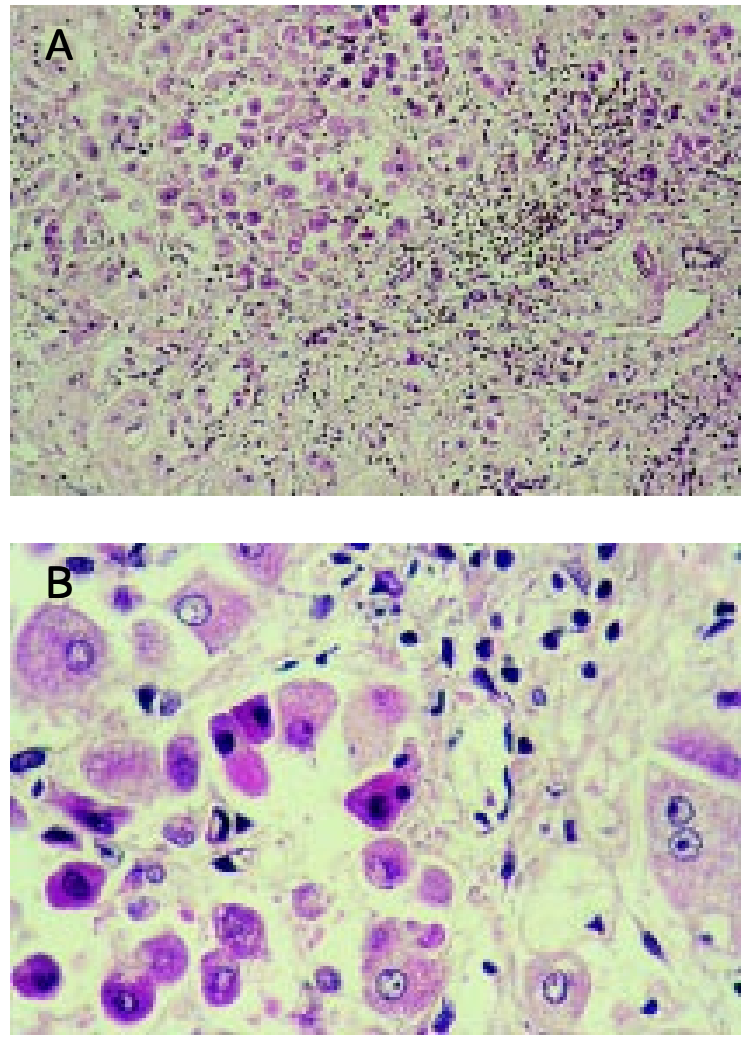

Figure 3. Histopathological aspects of extensive hepatic necrosis. A, Shrunken hepatocytes are detached from other swollen hepatocytes. Mononuclear inflammatory infiltrate is found, especially in the periportal area (case 3, H \& E, 60X). B, Several acidophilic "Councilman-like" bodies are immersed in the loose, edematous liver tissue. At the center, one lymphocyte is found inside an acidophilic hepatocyte (emperipolesis) (case 3, $\mathrm{H}$ $\& E, 150 X)$. 
for primary biliary cirrhosis) with corticosteroid and azathioprine.

Another histopathological examination of a liver biopsy obtained after a few months of treatment detected liver cirrhosis with interface hepatitis, compatible with the autoimmune pattern. No viral DNA or antigen was detected in the liver tissue at that time. After one year of treatment, case 3 achieved a complete response to immunosuppression, reinforcing the initial hypothesis of autoimmune hepatitis. This time course is also consistent with infectious hepatitis in which the B19 infection was resolved.

\section{Discussion}

In the present study, evidence for parvovirus B19 infection (monitored by anti-B19 IgM antibodies) was found in three (2.3\%) of 129 cases of non-A-E hepatitis.

Although B19 IgM antibodies are rarely found in patients not associated with an outbreak and without an illness suggesting parvovirus infection (25), there always is the possibility of false-positive results among these cases, even when using highly accurate tests (26). Thus, we have confirmed the presence of parvovirus infection in the liver using two other methods, PCR and immunohistochemistry.

One patient (case 2) showed chronic liver dysfunction with the histological pattern of cirrhosis, whereas case 1 had only minor histological lesions. No parvovirus DNA or VP1 antigen was found in the liver tissue of these patients. The B19 diagnosis in these two cases could simply represent intercurrent infections. Both patients were older than 70 years, asymptomatic concerning liver disease, had undergone previous surgeries and their hepatic disease had been diagnosed by a liver biopsy performed during surgery due to other reasons. Parvovirus B19 infection in chronic hepatitis cases has been reported by several authors. Indeed, this virus was found originally in a patient with chronic hepatitis
B (27), but the finding of persistent asymptomatic infections initially ruled out a possible etiological role (28).

Case 3 was a 56-year-old woman with a severe hepatic clinical picture and severe liver damage (submassive necrosis). Parvovirus B19 DNA and VP1 antigen were detected in the liver biopsy confirming the presence of active viral infection. Remarkably, several liver cells positive for VP1 antigen were swollen or undergoing acidophilic retraction, raising the hypothesis of a possible direct role of the virus in these hepatocellular lesions. This patient also showed isolated antimitochondrial antibody and was treated for autoimmune hepatitis with corticosteroid and azathioprine, showing a good response to this therapy, at least regarding the levels of serum aminotransferases and the disappearance of submassive hepatic necrosis. However, the autoimmune cirrhosis has already been settled.

The results obtained for case 3 corroborate other data providing evidence that parvovirus B19 may be a cause of hepatic dysfunction by mechanisms that are not yet elucidated (3-12). Some authors suggest a direct effect of parvovirus B19 infection after interaction with its cellular receptors, the erythrocyte $\mathrm{P}$ antigens, which are present on erythroid and liver cells (29). Furthermore, B19 DNA has been detected in liver tissue from fulminant hepatic failure cases (5). The time course of hepatitis in case 3 is also consistent with infectious hepatitis in which the B19 infection was resolved.

Another possible mechanism may involve the immune system, as reported in the virusassociated hemophagocytic syndrome after infection with B19 (30). Viral infection may induce increased levels of cytokines such as interferon- $\gamma$ and tumor necrosis factor- $\alpha$, that deregulate the phagocytic system, leading to pancytopenia and/or hepatic dysfunction (31). Parvovirus B19 has also been associated with other immunological diseases (3234 ), and the induction of different autoanti- 
bodies, including antimitochondrial ones, in patients infected with this virus has been reported $(35,36)$.

This second hypothesis seems more likely since parvovirus B19 DNA and VP1 antigen were detected only in the first biopsy, but not in another one obtained several months later. Another clue for a possible immuno-medi- ated pattern of liver lesion is the strict relation of lymphocytes to damaged hepatocytes, as demonstrated by the emperipolesis depicted in Figure 2B. This mechanism can also explain the association found in this case with antimitochondrial antibodies, even after viral clearance (i.e., in the absence of detectable virus in the liver).

\section{References}

1. Erdman DD \& Durigon EL (1995). Human parvovirus B19. Diagnostic procedures. In: Lennette EH, Lennette DA \& Lennette ET (Editors), Diagnostic Procedures of Viral, Rickettsial and Chlamydial Infections. 7th edn. American Public Health Association, Inc., Washington, DC, 495-503.

2. Torok TJ (1992). Parvovirus B19 and human disease. Advances in Intemal Medicine, 37: 431-455.

3. Tsuda H (1993). Liver dysfunction caused by parvovirus B19. American J oumal of Gastroenterology, 88: 1463 (Letter).

4. Yoto $\mathrm{Y}, \mathrm{Kudoh} \mathrm{T}$, Asanuma $\mathrm{H}$, Numazaki K, Tsutsumi Y, Nakata S \& Chiba S (1994). Transient disturbance of consciousness and hepatic dysfunction associated with human parvovirus B19 infection. Lancet, 344: 624-625.

5. Yoto Y, Kudoh T, Haseyama K, Suzuki N \& Chiba S (1996). Human parvovirus B19 infection associated with acute hepatitis. Lancet, 347: 868-869.

6. Langnas AN, Markin RS, Cattral MS \& Naides SJ (1995). Parvovirus B19 as a possible causative agent of fulminant liver failure and associated aplastic anemia. Hepatology, 22: 1661-1665.

7. Naides SJ , Karetnyi YV, Cooling LL, Mark RS \& Langnas NA (1996). Human parvovirus B19 infection and hepatitis. Lancet, 347: 1563-1564.

8. Hillingso J G, J ensen IP \& Tom-Petersen L (1998). Parvovirus B19 and acute hepatitis in adults. Lancet, 351: 955-956.

9. Longo $G$, Luppi $M$, Bertesi $M$, Ferrara $L$, Torelli G \& Emilia G (1998). Still's disease, severe thrombocytopenia, and acute hepatitis associated with acute parvovirus B19 infection. Clinical Infectious Diseases, 26: 994-995.

10. Pardi DS, Romero Y, Mertz LE \& Douglas DD (1998). Hepatitis-associated aplastic anemia and acute parvovirus B19 infection: a report of two cases and a review of the literature. American J oumal of Gastroenterology, 93: 468-470.
11. Sokal EM, Melchior M, Comu C, Vandenbroucke AT, Buts JP, Cohen BJ \& Burtonboy G (1998). Acute parvovirus B19 infection associated with fulminant hepatitis of favourable prognosis in young children. Lancet, 352: 1739-1741.

12. Bemuau J, Durand F \& Valla D (1999). Parvovirus B19 infection and fulminant hepatitis. Lancet, 353: 754-755.

13. Yamamoto $T$, Ise $K$, Nakashima $K$, Hayashi J , Nunoue T\& Kashiwagi S (1996). Parvovirus B19 as a trigger for spontaneous bacterial peritonitis in a patient with cirrhotic ascites. American J ournal of Gastroenterology, 91: 1857-1859.

14. Ndimbie OK, Frezza E, J ordan J A, Koch W \& van Thiel DH (1996). Parvovirus B19 in anemic liver transplant recipients. Clinical Diagnosis and Laboratory Immunology, 3: 756-760.

15. Garson J A, Ring C, Tuke P \& Tedder RS (1990). Enhanced detection by PCR of hepatitis C virus RNA. Lancet, 337: 878879.

16. Garson J A, Ring CJ \& Tuke PW (1991). Improvement of HCV genome detection with "short" PCR products. Lancet, 338: 1466-1467.

17. Chomczynski $P \&$ Sacchi N (1987). Singlestep method of RNA isolation by acid guanidinium thiocyanate-phenol-chloroform extraction. Analytical Biochemistry, 162: 156-159.

18. Erdman DD, Usher J M, Tsou C, Caul EO, Gary GW, Kajigaya S, Young NS \& Anderson LJ (1991). Human parvovirus B19 specific IgG, IgA and IgM antibodies and DNA in serum specimens from persons with erythema infectiosum. J ournal of Medical Virology, 35: 110-115.

19. Kajigaya $S$, Fujii $H$, Field A, Anderson S, Rosenfeld S, Anderson LJ, Shimada T \& Young NS (1991). Self-assembled B19 parvovirus capsids, produced in a baculovirus system, are antigenically and immunogenically similar to native virions. Proceedings of the National Academy of Sci- ences, USA, 88: 4646-4650.

20. Durigon EL, Erdman DD, Gary GW, Pallansch MA, Torok $\Pi \mathrm{Q} \&$ Anderson $\mathrm{LJ}$ (1993). Multiple primer pairs for polymerase chain reaction (PCR) amplification of human parvovirus B19 DNA. J oumal of Virological Methods, 44: 155-165.

21. Abuaf $\mathrm{N}$, J ohanet $\mathrm{C} \&$ Homberg J-C (1991). Autoantibody pattern in primary biliary cirrhosis. In: Krawitt EL \& Wiesner RH (Editors), Autoimmune Liver Diseases. Raven Press, New York, 93-109.

22. Cançado ELR, Vilas-Boas LS, AbrantesLemos CP, Novo NF, Porta G, Da Silva LC \& Laudanna AA (1996). Heat serum inactivation as a mandatory procedure for antiactin antibody detection in cell culture. Hepatology, 16: 1098-1104.

23. Berg PA \& Klein R (1991). Autoantibodies in autoimmune chronic active hepatitis. In: Krawitt EL \& Wiesner RH (Editors), Autoimmune Liver Diseases. Raven Press, New York, 122-141.

24. Wood GS \& Wamke R (1981). Suppression of endogenous avidin-binding activity in tissues and its relevance to biotin-avidin detection systems. J oumal of Histochemistry and Cytochemistry, 29: 1196-1201.

25. McOmish F, Yap PL, J ordan A, Hart N \& Cohen BJ (1993). Detection of parvovirus B19 in donated blood: a model system for screening by polymerase chain reaction. J ournal of Clinical Microbiology, 31: 323328.

26. Brown KE, Buckley $M M$, Cohen BJ \& Samuel D (1989). An amplified ELISA for the detection of parvovirus B19 IgM using monoclonal antibody to FITC. J oumal of Virological Methods, 26: 189-198.

27. Cossart YE, Field AM, Cant B \& Widdows D (1975). Parvovirus-like particles in human sera. Lancet, 1: 72-73.

28. Sasaki T, Murai C, Muryoi T, Takahashi Y, Munakata Y, Sugamura K \& Abe K (1995). Persistent infection of human parvovirus B19 in a normal subject. Lancet, 346: 851 (Letter). 
29. Brown KE, Anderson SM \& Young NS (1993). Erythrocyte P antigen: cellular receptor for B19 parvovirus. Science, 262: 114-117.

30. Muir K, Todd WT, Watson WH \& Fitzsimons E (1992). Viral-associated haemophagocytosis with parvovirus-B19-related pancytopenia. Lancet, 339: 1139-1140.

31. Ohga S, Matsuzaki A, Nishizaki M, Nagashima T, Kai T, Suda M \& Ueda K (1993). Inflammatory cytokines in virus-associated hemophagocytic syndrome. Interferon-gamma as a sensitive indicator of disease activity. American J ournal of Pediat- ric Hematology and Oncology, 15: 291298.

32. Pattison J R (1987). B19 virus - a pathogenic human parvovirus. Blood Reviews, 1: 58-64.

33. Kerr J R, Coyle PV, DeLeys RJ \& Patterson CC (1996). Follow-up study of clinical and immunological findings in patients presenting with acute parvovirus B19 infection. J ournal of Medical Virology, 48: 6875.

34. Assy N, Rosenthal E, Hazani A, Etzioni A \& Baruch Y (1997). Human parvovirus B19 infection associated with idiopathic thrombocytopenic purpura in a child following liver transplantation. J ournal of Hepatology, 27: 934-936.

35. Kerr J R \& Boyd N (1996). Autoantibodies following parvovirus B19 infection. J ournal of Infection, 32: 41-47.

36. Hansen KE, Arnason J \& Bridges AJ (1998). Autoantibodies and common viral diseases. Seminars in Arthritis and Rheumatism, 27: 263-271.

37. J ohnson PJ \& McFarlane IG (1993). Meeting Report: International Autoimmune Hepatitis Group. Hepatology, 18: 9981005. 